\title{
Immunochemical characterisation of a 29-Kda surface- associated molecule of Entamoeba histolytica and its recognition by serum from patients with amoebiasis
}

\author{
R. K. SHANDIL and V.K. VINAYAK*
}

Division of Experimental Parasitology and Parasitic Immunology, Department of Experimental Medicine, Postgraduate Institute of Medical Education and Research, Chandigarh 160 012, India

\begin{abstract}
Summary. A 29-Kda cytotoxic molecule of axenically-grown pathogenic Entamoeba histolytica (strain HM1) was purified from an amoebic extract by immuno-affinity chromatography with monoclonal antibodies. Immunoreactivity of the purified $29-\mathrm{Kda}$ molecule altered significantly $(p<0.01)$ after exposure to heat or trypsin, but remained unaltered after treatment with sodium metaperiodate. The 29-Kda molecule was recognised by serum from each of 13 patients with amoebic liver abscess. In an ELISA system, the molecule produced significantly higher $(p<0.01)$ OD readings with these serum samples than with samples from asymptomatic cyst passers. No serum from healthy subjects or from patients with idiopathic ulcerative colitis or giardiasis had antibodies that reacted with the 29-Kda molecule. The immune response to the 29-Kda amoebic protein in man may indicate a specific role for this molecule in invasive amoebiasis.
\end{abstract}

\section{Introduction}

Entamoeba histolytica is a protozoan parasite that infects 480 million people with 36 million cases of disabling colitis or extra-intestinal metastasis and 40000 deaths annually. ${ }^{1}$ Cytolysis of the target cells by amoebae is initiated by adhesion of amoebic trophozoites through surface lectins via specific receptors ${ }^{2}$ this is followed by cytolysis of target cells through the action of proteolytic enzymes, ${ }^{3-5}$ cytotoxins ${ }^{6}$ and enterotoxins. ${ }^{7,8}$ The trophozoites of $E$. histolytica cytolyse erythrocytes ${ }^{9}$ and other target cells such as Chinese Hamster Ovary cells (CHO), Baby Hamster Kidney cells (BHK), Maiden Derby Canine Kidney cells (MDCK) and Henle-407 cells by direct contact-dependent cytolysis. ${ }^{2,6}$ Thus, the surface-associated adhesive and cytotoxic molecule(s) are important in mediating host-parasite interactions. Several monoclonal antibodies (MAbs) have been developed and used widely to identify surface-associated molecules of amoebic trophozoites. A $220-\mathrm{Kda}$ protein that is inhibited by $N$-acetyl-D-glucosamine, ${ }^{10}$ a $170-\mathrm{Kda}$ lectin that is inhibited by $N$-acetyl-Dgalactosamine, ${ }^{11}$ a $112-\mathrm{Kda}$ lectin ${ }^{12}$ and a $96-\mathrm{Kda}$ protein ${ }^{13}$ have been implicated in the recognition of target cells by amoebae. Recently, $\mathrm{we}^{14}$ and others ${ }^{15-17}$ have reported recognition of several amoebic antigens by serum from patients with amoebiasis. An epitope of a 29-Kda surface-associated protein of $E$.

Received 22 Jan. 1991 ; revised version accepted 4 April 1991. * Correspondence should be sent to Dr V. K. Vinayak. histolytica, identified by MAbs, ${ }^{18}$ has been shown to mediate adhesion and cytoxicity of amoebic trophozoites to the target cells. ${ }^{19}$ Furthermore, amoebae from asymptomatic cases showed little or no evidence of expression of a (29-30)-Kda molecule. ${ }^{18,20}$ Thus the (29-30)-Kda protein may have a role in mediating the amoebic disease process. In the present study we have sought to purify the $29-\mathrm{Kda}$ molecule by affinity chromatography with MAbs, to characterise it immunochemically, and to investigate its recognition by serum from patients with amoebiasis.

\section{Materials and methods}

\section{Preparation of antigen}

E. histolytica (strain HM1) trophozoites grown axenically in Trypticase-Panmede-Serum (TPS-I) medium were harvested in phosphate-buffered saline (PBS; pH 7.2) and disintegrated ultrasonically in a sonicator (MSE Ltd, Crawley, Sussex) with 10 15-s bursts. ${ }^{19}$ The sonicated material was designated crude amoebic extract (CAE). The protein content of CAE was determined by the method of Lowry et al. ${ }^{21}$

\section{Monoclonal antibodies (MAbs)}

A panel of MAbs developed by us was used to identify the 29-Kda molecule of $E$. histolytica. A clone of cells, P4C4F8 (C8), produced $\mathrm{MAb}^{\mathrm{C} 8}$, of $\mathrm{IgG}_{1}$ isotype, which recognised the 29-Kda molecule of $E$. 
histolytica trophozoites. ${ }^{19}$ MAb C8-producing cells were propagated as ascites in BALB/c mice and were precipitated by ammonium sulphate $45 \% \mathrm{w} / \mathrm{v}$. The precipitated MAb was redissolved in PBS ( $\mathrm{pH} \mathrm{7.2)}$ and dialysed extensively against distilled water. ${ }^{22}$

\section{Affinity purification of 29-Kda antigen}

The 29-Kda amoebic antigen was affinity purified as described earlier. ${ }^{23}$ Briefly, $5 \mathrm{mg}$ of MAb C8 directed at the 29-Kda antigen was covalently coupled to $1 \mathrm{ml}$ of cyanogen bromide-activated sepharose-4 B gel in $0.1 \mathrm{M}$ borate buffer saline, $\mathrm{pH} 8.3$. A portion containing $5 \mathrm{mg}$ of CAE protein was applied to an immuno-adsorbent column previously equilibrated with PBS (pH 7.2) at $4^{\circ} \mathrm{C}$ for $3 \mathrm{~h}$. The bound antigen was eluted at $4^{\circ} \mathrm{C}$ with $0.1 \mathrm{M}$ glycine- $\mathrm{HCl}$ buffer, $\mathrm{pH}$ 2.5. Several identical elutions of CAE protein were made through affinity gel. The fractions containing protein were pooled, dialysed extensively against distilled water and concentrated by lyophilisation (Kontron Instruments, Zurich, Switzerland).

\section{Sodium dodecyl sulphate-polyacrylamide gel electrophoresis (SDS-PAGE) and Western immunoblotting}

The purity of affinity-purified antigen was confirmed by SDS-PAGE. ${ }^{24}$ The specificity was investigated by Western immunoblotting. ${ }^{25}$ Briefly, $100 \mu \mathrm{g}$ of CAE protein or $40 \mu \mathrm{g}$ of affinity-purified antigen was subjected to electrophoresis in a $5 \%$ stacking gel and a $10 \%$ separating gel under reducing conditions in an electrophoretic cell (BioRad Laboratories, Richmond, CA, USA) at $25 \mathrm{~mA}$ for $4 \mathrm{~h}$. Resolved proteins from gels were either stained or transferred on to nitrocellulose paper $(0 \cdot 2-\mu \mathrm{m}$ pore diameter $)$ at $200 \mathrm{~mA}$ for $3 \mathrm{~h}$. The strips were blocked with bovine serum albumin (BSA) $3 \%$ and incubated with MAb C8 or hyperimmune serum obtained from mice immunised with CAE, followed by incubation with anti-mouse-HRP conjugate (Dakopatts a/s Glostrup, Denmark). The colour reaction was developed with $3 \mathrm{mg}$ of 4-chloro1-naphthol in $6 \mathrm{ml}$ of PBS, pH 7.2, and $5 \mu \mathrm{l}$ of $\mathrm{H}_{2} \mathrm{O}_{2}$ as substrate.

\section{Physico-immunochemical characterisation of the 29-Kda antigen}

Immunoreactivity of the $29-\mathrm{Kda}$ antigen after heating and exposure to trypsin or sodium metaperiodate was assessed in an ELISA system. ${ }^{26}$ The sensitivity to heat was determined by exposing $29-\mathrm{Kda}$ antigen to $60^{\circ} \mathrm{C}$ or $100^{\circ} \mathrm{C}$ (boiling) for $10 \mathrm{~min}$ before coating on to the ELISA plate. The effect of proteolytic digestion was determined by treating wells coated with $29-\mathrm{Kda}$ antigen with trypsin $(10,100$ or $1000 \mu \mathrm{g} /$ $\mathrm{ml}$ ) at $37^{\circ} \mathrm{C}$ for $2 \mathrm{~h}$. Wells containing untreated antigen served as controls. The periodate oxidation was accomplished by treating wells coated with the 29-
$\mathrm{Kda}$ antigen with $0.025 \mathrm{M}, 0.05 \mathrm{M}$ or $0.1 \mathrm{M}$ sodium metaperiodate in $20 \mathrm{mM}$ sodium acetate buffer, $\mathrm{pH}$ 4.5 , in the dark at $4^{\circ} \mathrm{C}$ for $24 \mathrm{~h}$. Antigen-coated wells treated with acetate buffer alone were included as controls. Altered immunoreactivity of treated antigen was assessed by incubating with MAb C8 (1 in 1000) and then with anti-mouse-HRP conjugate. The reaction was developed with $o$-phenylene-diamine (OPD) as substrate $(5 \mathrm{mg}$ of OPD in $10 \mathrm{ml}$ of citrate buffer, pH 5.0, and $5 \mu$ l of $\mathrm{H}_{2} \mathrm{O}_{2}$ ). The effect of heat, trypsin and periodate treatments was determined by comparing optical density (OD) values of treated wells with untreated control wells. Each experiment was set up in triplicate and repeated at least twice.

\section{Recognition of 29 -Kda protein by human serum}

A total of 33 serum samples was collected from confirmed cases of amoebic liver abscess (13 patients), asymptomatic amoebic cyst passers (five patients), idiopathic ulcerative colitis (five patients) and giardiasis (five patients) and from five healthy subjects. The criteria for diagnosis of these patients have been reported elsewhere. ${ }^{27}$ Each serum sample was tested against the 29-Kda affinity-purified amoebic protein in an ELISA system. ${ }^{28}$ Briefly, the ELISA was performed in microtitration plates (M/S Costar Corporation, Broadway, Cambridge, MA, USA) by coating wells with a $100-\mu 1$ portion containing affinitypurified $29-\mathrm{Kda}$ protein, $1 \mu \mathrm{g} / \mathrm{ml}$ in $0.05 \mathrm{M}$ carbonate buffer, pH 9.6. Wells were blocked with BSA $3 \%$ and incubated with each serum diluted 1 in 4000 . After treatment with anti-human-HRP conjugate (The Binding Site Ltd, Edgbaston, Birmingham) diluted 1 in 4000 , the colour reaction was developed with OPD as substrate. The reaction was stopped by adding $50 \mu \mathrm{l}$ of $6 \mathrm{~N} \mathrm{H}_{2} \mathrm{SO}_{4}$ and the OD was measured at $492 \mathrm{~nm}$ in an ELISA reader (Uniskan-1 ; Lab Systems, Helsinki, Finland).

\section{Results}

\section{Affinity purification of 29-Kda antigen}

The 29-Kda amoebic protein was successfully eluted from the affinity column by elution under acidic conditions (fig. 1). SDS-PAGE analysis of purified antigen revealed a single band at the $29-\mathrm{Kda}$ position (fig. 2). Immunoblotting of affinity-purified $29-\mathrm{Kda}$ antigen with hyperimmune serum or $\mathrm{MAbC} \mathrm{C}$ revealed a discrete single band at a position corresponding to a molecular mass of 29-Kda (fig. 3).

\section{Physico-immunochemical characterisation}

The exposure of affinity-purified $29-\mathrm{Kda}$ antigen at $60^{\circ} \mathrm{C}$ significantly reduced its reactivity to $\mathrm{MAb} \mathrm{C} 8$ and exposure at $100^{\circ} \mathrm{C}$ almost abolished its immunoreactivity (fig. 4a). Similarly, proteolytic digestion of 


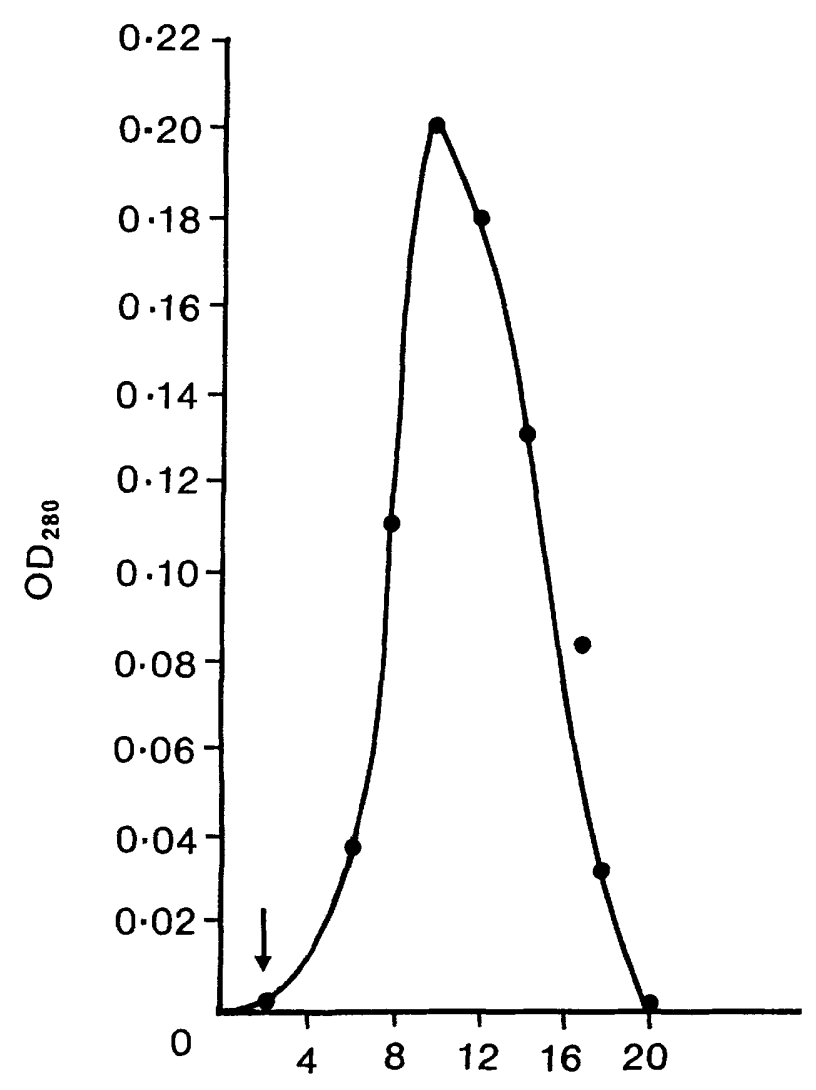

Elution volume (2-ml fractions)

Fig. 1. Affinity gel elution profile of the $29-\mathrm{Kda}$ molecule of $E$. histolytica.

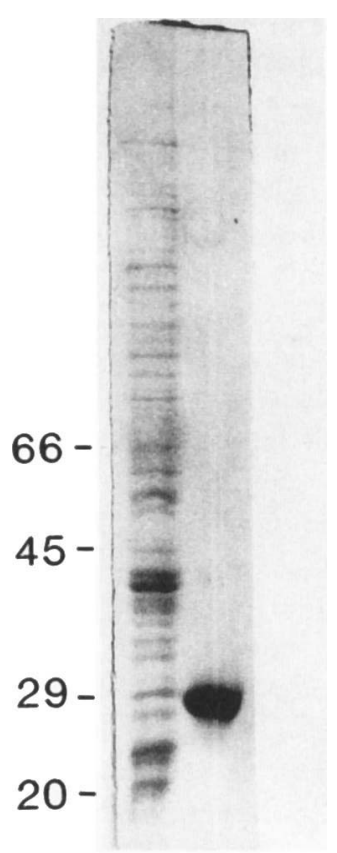

\section{A B}

Fig. 2. SDS-PAGE of E. histolytica antigens. Lane (A) crude amoebic extract (CAE) antigen; (B) affinity-purified 29-Kda antigen.

the 29-Kda antigen with trypsin reduced its immunoreactivity to MAb C8 progressively as the concentration was raised (fig. 4b). However, the immunoreactivity of the $29-\mathrm{Kda}$ antigen was unaffected by sodium metaperiodate oxidation (fig. $4 \mathrm{c}$ ).

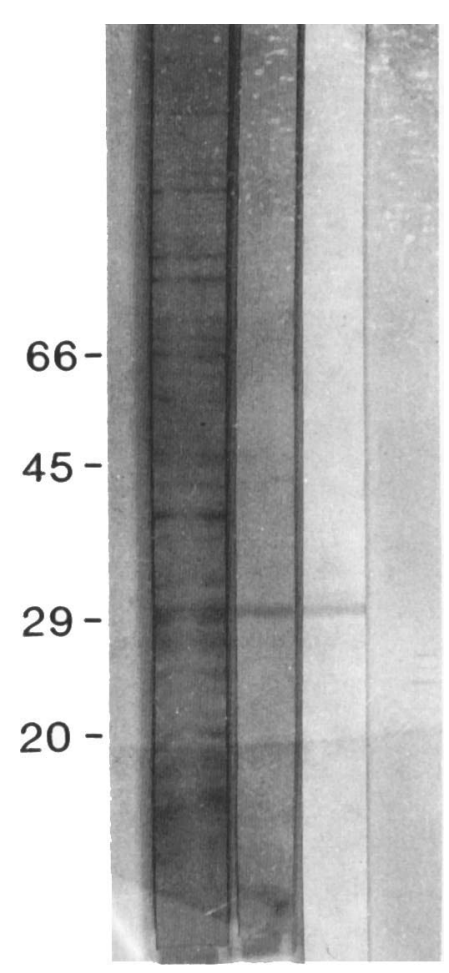

A B C

Fig. 3. SDS-PAGE immunoblots of $E$. histolytica antigens: (A) CAE antigen with anti-amoebic hyperimmune serum;(B) affinity-purified 29-K da protein with hyperimmune serum; and (C) 29-Kda protein with MAb C8.

\section{Recognition of 29-Kda protein by human serum}

The mean OD value of antibodies to the $29-\mathrm{Kda}$ protein in serum from healthy subjects was 0.022 (SD 0.015 ) (fig. 5). A cut-off OD value for significance was calculated to be 0.052 - the mean plus two SD of the OD values observed in healthy subjects. The mean $O D$ values of serum from patients with giardiasis and ulcerative colitis were below the cut-off value. Serum from 13 cases of amoebic liver abscess recognised the 29-Kda antigen in the ELISA system; the mean OD value of anti-29-Kda antibodies in these patients was 0.777 (SD 0.023). OD values obtained with serum from asymptomatic cyst passers was $0 \cdot 220$ (SD 0.046). Although the $29-\mathrm{Kda}$ amoebic protein could be recognised by serum samples from asymptomatic cyst passers, their reactivity was significantly lower (mean OD 0.22 , SD 0.046 ) than the reactivity (mean OD 0.777 , SD 0.023 ) of serum from patients with hepatic amoebiasis.

\section{Discussion}

The involvement of surface-associated molecules in modulation of the disease process requires recognition and development of specific immune responses by the host's immune system. Often, the proteins expressed on the cell surface of microbes are important in mediating interactions with target cells, but the integral membrane proteins have extensive hydropho- 


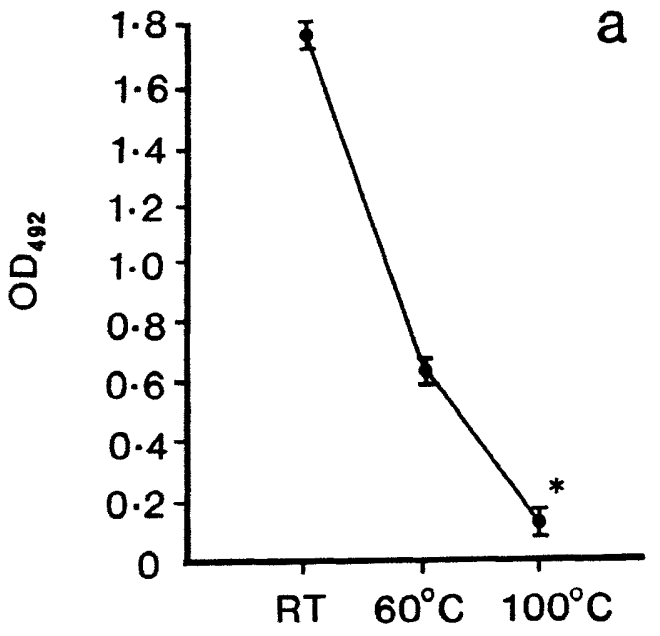

Heat treatment

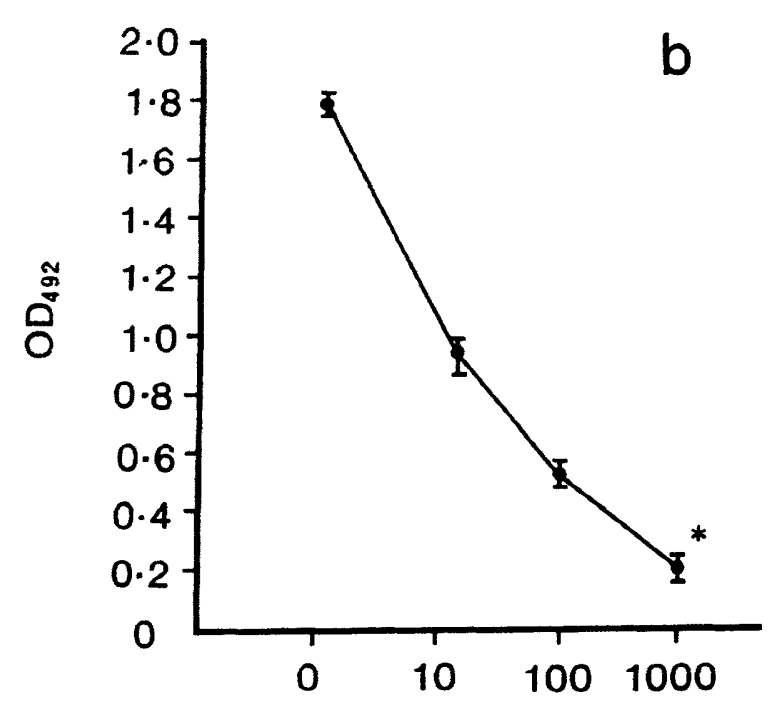

Trypsin concentration $(\mu \mathrm{g} / \mathrm{ml})$

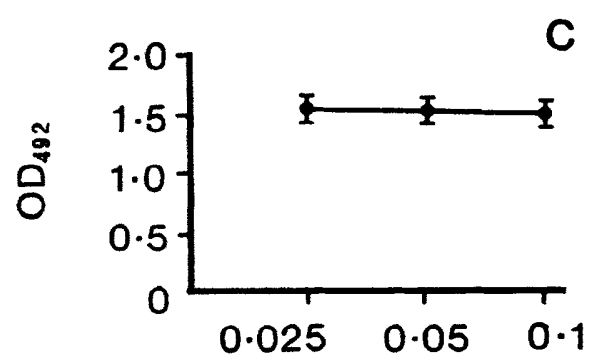

\section{$\mathrm{NaIO}_{4}$ concentration $(\mathrm{M})$}

Fig. 4. Immunoreactivity of affinity-purified $29-\mathrm{Kda}$ molecule after (a) heat treatment, (b) proteolytic digestion with trypsin, (c) sodium metaperiodate oxidation (mean OD of two sets tested in triplicate); ${ }^{*} \mathrm{p}<0.01$.

bic regions making them difficult to purify and characterise. In this study, we have successfully purified a protein that we had identified earlier as an epitope of a membrane-associated antigen expressed

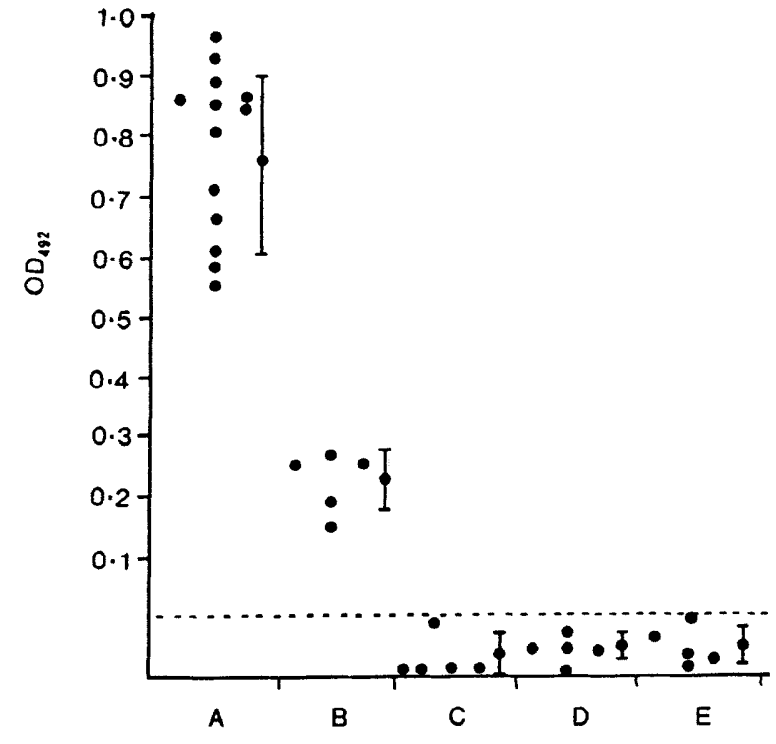

Fig. 5. Recognition of 29-Kda protein of $E$. histolytica in ELISA by serum from (A) patients with amoebic liver abscess, (B) asymptomatic cyst passers; (C) patients with idiopathic ulcerative colitis, (D) patients with giardiasis, and (E) healthy subjects. The broken line represents the cut-off OD value; bars represent SD.

on the surface of $E$. histolytica trophozoites. ${ }^{19}$ This antigen was found to be free from other amoebic proteins and has a molecular mass of $29-\mathrm{Kda}$. Immunochemical characterisation of the epitope revealed it to be protein in nature-it was heatsensitive and proteolytic digestion of purified antigen reduced its immunoreactivity, whereas sodium metaperiodate oxidation did not. The $29-\mathrm{Kda}$ molecule was recognised by the human host and specific antibodies were generated in response to amoebic infection. However, the antibody response to the $29-\mathrm{Kda}$ molecule in patients with amoebic liver abscess was significantly higher $(p<0.01)$ than that observed in asymptomatic amoebic cyst passers. This suggests a variable degree of recognition of this molecule in man. Since the $29-\mathrm{Kda}$ molecule is a component of the amoebic plasma membrane, a significant immune response may be generated only if the amoebic trophozoite expresses this molecule. The low level of anti-29-Kda antibodies in cyst passers may indicate that the $29-\mathrm{Kda}$ molecule is poorly expressed by amoebic trophozoites in the gut lumen. A recent study by Tachibana et al. ${ }^{20}$ indicated that amoebae isolated from patients with invasive amoebiasis strongly expressed a $30-\mathrm{Kda}$ antigen, whereas amoebae isolated from asymptomatic amoebic cyst passers expressed little or none of this antigen. It is possible that hyperexpression of the (29-30)-Kda molecule may correlate with the invasive potential of the parasite, and thus may be important in virulence.

We thank Dr D. Bhasin of the Department of Gastroenterology, Postgraduate Institute of Medical Education and Research, Chandigarh for providing clinical material. This work was supported by grant No. 11/(25)/83-STP-II from the Department of Science and Technology (Government of India), New Delhi. 


\section{References}

1. Walsh JA. Problems in recognition and diagnosis of amebiasis: estimation of the global magnitude of morbidity and mortality. Rev Infect Dis 1986; 8: 228-238.

2. Ravdin JI. Pathogenesis of disease caused by Entamoeba histolytica: studies of adherence, secreted toxins, and contact-dependent cytolysis. Rev Infect Dis 1986; 8: 247260.

3. Gitler C, Mirelman D. Factors contributing to the pathogenic behavior of Entamoeba histolytica. Annu Rev Microbiol $1986 ; 40: 237-261$

4. Lushbaugh WB, Hofbauer AF, Pittman FE. Proteinase activities of Entamoeba histolytica cytotoxin. Gastroenterology 1984; 87: 17-27.

5. De Meester F, Shaw E, Scholze H, Stolarsky T, Mirelman D. Specific labeling of cysteine proteinases in pathogenic and non-pathogenic Entamoeba histolytica. Infect Immun 1990; 58: 1396-1401.

6. Ravdin JI, Croft BY, Guerrant RL. Cytopathogenic mechanisms of Entamoeba histolytica.J Exp Med 1980; 152: 377390.

7. Lushbaugh WB, Kairalla AB, Cantey JR, Hofbauer AF, Pittman FE. Isolation of cytotoxin-enterotoxin from Entamoeba histolytica. J Infect Dis 1979; 139: 9-17.

8. McGowen K, Deneke CF, Thorne GM, Gorbach SL. Entamoeba histolytica cytotoxin: purification, characterization, strain virulence, and protease activity. J Infect Dis 1982; 146: 616-625.

9. Ravdin JI, Guerrant RL. Role of adherence in cytopathogenic mechanisms of Entamoeba histolytica: study with mammalian tissue culture cells and human erythrocytes. $J$ Clin Invest 1981 ; 68: 1305-1313.

10. Meza I, Cázares F, Rosales-Encina JL, Talamás-Rohana P, Rojkind M. Use of antibodies to characterize a 220 kilodalton surface protein from Entamoeba histolytica. $J$ Infect Dis 1987; 156: 798-805.

11. Petri MA, Smith RD, Schlesinger PH, Murphy CF, Ravdin JI. Isolation of galactose-binding lectin that mediates the in vitro adherence of Entamoeba histolytica.J Clin Invest 1987; 80: $1238-1244$.

12. Rodriguez MA, Harnenedez F, Santos L, Valdez A, Orozoco E. Entamoeba histolytica: molecules involved in the target cell-parasite relationship. Mol Biochem Parasitol 1989; 37 . $87-100$.

13. Torian BE, Lukehart SA, Stamm WE. Use of monoclonal antibodies to identify, characterize, and purify a 96,000 dalton surface antigen of pathogenic Entamoeba histolytica. $J$ Infect Dis 1987; 156: 334-343.

14. Shandil RK, Vinayak VK. Immunoreactivity of Entamoeba histolytica antigens with sera from amebic patients. Med Microbiol Immunol 1990; 179: 263-269.

15. Petri WA, Joyce MP, Broman J, Smith RD, Murphy CF, Ravdin JI. Recognition of galactose- or $N$-acetylgalactosamine-binding lectin of Entamoeba histolytica by human immune sera. Infect Immun 1987; 55: 2327-2331.

16. Joyce MP, Ravdin JI. Antigens of Entamoeba histolytica recognized by immune sera from liver abscess patients. $A m$ J Trop Med Hyg 1988; 38: 74-80.

17. Bhattacharya A, Bhattacharya S, Sharma, MP, Diamond LS Metabolic labeling of Entamoeba histolytica antigens: characterization of a $28-\mathrm{Kda}$ major intracellular antigen. Exp Parasitol 1990; 70: 255-263.

18. Torian BE, Flores BM, Stroeher VL, Hagen FS. cDNA sequence analysis of a 29-Kda cysteine-rich surface antigen of pathogenic Entamoeba histolytica. Proc Natl Acad Sci USA 1990;87: 6358-6362.

19. Vinayak VK, Shandil RK. Recognition of a 29-Kda surface associated adhesive molecule of Entamoeba histolytica by monoclonal antibodies. FEMS Microbiol Immunol 1990; 64: $169-178$.

20. Tachibana H, Kobayashi S, Kato Y, Nagakura K, Kaneda Y, Takeuchi $T$. Identification of a pathogenic isolate-specific $30,000 \mathrm{M}_{\mathrm{r}}$ antigen of Entamoeba histolytica by using monoclonal antibody. Infect Immun 1990; 58: 955-960.

21. Lowry OH, Rosebrough NJ, Farr AL, Randall RJ. Protein measurement with Folin phenol reagent. J Biol Chem 1951; 193: $265-275$.

22. Hudson L, Hay FC (eds) Practical Immunology, 2nd edn. Oxford, Blackwell Scientific Publications. 1980: 226-228.

23. Vinayak VK, KumKum, Khanna R. Serum antibodies to giardial surface antigens: lower titres in persistent than in non-persistent giardiasis. J Med Microbiol 1989; 30 : 207 212.

24. Laemmli UK. Cleavage of structural proteins during the assembly of the head of bacteriophage T4. Nature 1970; 227: $680-685$

25. Towbin H, Staehelin T, Gordon J. Electrophoretic transfer of proteins from polyacrylamide gels to nitrocellulose sheets : procedure and some applications. Proc Natl Acad Sci USA $1979 ; 76: 4350-4354$.

26. KumKum, Khanna R, Vinayak, VK. Characterisation of surface-associated antigens of axenic Giardia lamblia trophozoites and their recognition by human sera. Ind $J$ Med Res 1991; 93: 40-46.

27. Vinayak VK, Shandil RK, Bansal V, Singh K, Bhasin DK, Kaur U. Uses and limitations in the demonstration of specific circulating immune complexes in patients with amoebiasis. J Med Microbiol 1990; 32: 87-91.

28. Voller A, Bidwell DE, Bartlett A. Enzyme immunoassays in diagnostic medicine: theory and practice. Bull WHO 1976; 53: $55-65$. 